\title{
The Politics of Treaty Interpretation: Variations and Explanations Across International Tribunals
}

\author{
Joost Pauwelyn \\ Graduate Institute of International and Development Studies, Geneva \\ Manfred Elsig \\ World Trade Institute, University of Bern
}

\section{INTRODUCTION ${ }^{1}$}

International tribunals rely on interpretation of legal texts as a crucial tool in adjudication. What is puzzling is the increasingly wide variation we observe in treaty interpretation by international tribunals across policy areas and over time. The international relations (IR) literature has largely overlooked the factors that explain the extent and scope of treaty interpretation. While there is an extensive normative literature in international law (IL) as to the right way to interpret, empirical work still lacks mid-range theories to account for the observed variance of behaviour across international tribunals. This chapter tries to fill this gap by providing a conceptual toolkit inspired by IL and IR theories to approach the various types of interpretation (interpretation choices) and underlying explanations (demand side interpretation space and supply side interpretation incentives).

In IL scholarship, attention has focused on the normative question of how treaties should be interpreted, especially with reference to the Vienna Convention on the Law of Treaties (VCLT) referring, in turn, to text, context, object and purpose and preparatory works of a treaty (Gardiner 2008; Van Damme 2009). These Vienna Convention rules apply, in principle, to all international tribunals irrespective of their institutional set-up, subject matter or geographical scope. Divergence between international tribunals in the practical application of these rules of treaty interpretation has been pointed out (Weiler 2010). Yet, categorizing where exactly international tribunals have diverged in their approach and, especially, thinking about what factors

\footnotetext{
${ }^{1}$ We wish to thank Jeff Dunoff, Mark Pollack, Tonya Putnam and other participants at the Temple University Workshop for comments on an earlier draft and Susan Kaplan and Facundo Perez Aznar for research assistance.
} 
might explain these differences, has received little or no attention. Instead, divergence has been labelled as an incorrect application of the Vienna Convention rules or proof that these rules are outdated or should not fully apply to a particular tribunal (Klabbers 2010:33). This chapter leaves the normative issue aside and focuses on the descriptive and conceptual aspects: What is it that international tribunals actually do and how could this behaviour be explained, first, within the same tribunal operating over time and, second, across tribunals operating in different contexts or regimes?

In IR scholarship, increasing attention has been paid to the role of international tribunals (e.g. in the broader "legalization" debate or as agents vs. trustees) and to the design of dispute settlement mechanisms in international agreements (Koremenos 2007; Alter 2008a). Other studies have addressed the effects of proliferation of international tribunals and forum-shopping (Drezner 2006; Busch 2007). In addition, most of the commitment literature in IR focuses on the question why states sign or ratify international agreements and what factors explain the degree of implementation of or compliance with international agreements. Yet, what has been largely overlooked is the stage between commitment and compliance, more specifically, the process by which commitments are interpreted in the first place. While many actors in the realm of international politics may eventually influence the way treaty obligations are interpreted (in particular, treaty parties themselves), the key institutions (and usually the last resort) engaging in this process are increasingly international tribunals (Romano 2007). These tribunals are called upon to engage in an interpretation, precisely because member states or other actors that may have standing cannot agree among themselves on a way to read the commitments.

This chapter attempts to push the conceptual borders across both fields. After defining and discussing the increased importance of treaty interpretation (Part II), we first describe the five interpretation choices that international tribunals most commonly make (Part III). We then offer a framework that may explain these choices (Part IV). We provide illustrative examples to tease out our explanatory framework, but do not engage in proper empirical testing. At this stage, our goal is merely to demonstrate that tribunals have a varying degree of interpretation space within which they must select between different interpretative techniques. Understanding these techniques and the factors that may explain their adoption can, in turn, provide useful insights into the operation, role and optimal design of international tribunals. 


\section{DEFINITION AND IMPORTANCE OF TREATY INTERPRETATION}

For present purposes, treaty interpretation is the activity through which international tribunals give meaning to a treaty in the context of a particular case or fact pattern. Interpreting legal texts is what courts do. International tribunals are no exception. Whereas domestic courts most commonly interpret and apply contracts, statutes or constitutions, international tribunals most commonly interpret and apply treaties. In most cases, international tribunals must interpret treaties to decide whether or not a party is complying with the treaty. In case treaty breach is found, treaty interpretation intervenes at a crucial stage between commitment and compliance.

Although international tribunals have existed for more than a century the question of treaty interpretation has never attracted as much attention as it does today. We see three main reasons for this: fragmentation, frequency and the peculiar nature of treaties.

First, much of today's hype around treaty interpretation is due to the proliferation or, as others put it, fragmentation, of international treaties and tribunals (Pauwelyn 2003). Seen from this fragmentation angle, treaty interpretation can be part of the problem. Different tribunals may interpret the same rules differently, each having their own guiding objective, underlying value system and interpretative community, thereby contributing to the cacophony of fragmentation (Crema 2010). Yet, treaty interpretation can also be part of the solution to fragmentation. Treaty interpretation may offer shared hermeneutics in search of a more systemic integration of diverse treaties and tribunals and inject a degree of coherence into the fragmented landscape of international law (Bianchi 2010).

Second, from a more practical perspective, with more tribunals in place, the question of how tribunals interpret treaties has moved from a largely normative, academic debate, to a day to day activity of deciding real cases which are subsequently closely scrutinized by a variety of affected actors beyond the state parties themselves. In less than twenty years both the numbers of international tribunals and the number of cases they are asked to decide have dramatically increased.

Third, the question of how international tribunals interpret poses a particular paradox compared to domestic legal systems. Treaties tend to be more incomplete contracts than national texts, because of high transaction costs and future uncertainties 
(Allott 1999:43). This is especially the case for multilateral treaties (many parties must agree on one single text, often left deliberately vague and redacted in multiple languages) as well as for treaties between countries with highly diverse interests and backgrounds (leaving even the most basic notions or terms open to disagreement or different interpretations). Since more questions are left open (Voeten 2008), choice of interpretative method becomes more important. At the same time, since treaties are concluded between sovereign states, treaty parties remain, for the same reasons that explain treaty ambiguity (party consent, diversity of interests) wary of delegating discretionary power to international tribunals (sensitivity of treaties). As a result, international tribunals must interpret more (treaties as incomplete contracts) but in doing so are also under closer scrutiny (treaties as contracts between sovereign states). Making this combination even more difficult is a third element: the rigidity of treaties once they are enacted. Whereas parliaments can correct domestic courts, in most cases, by simple majority, "legislative correction" of international tribunals by treatymakers is subject to the consent rule. This means that all parties to the treaty, including the party that benefited from the "wrong interpretation" by the tribunal, must agree to change that interpretation or adapt the treaty to keep it up to date. Thus the rigidity of treaties makes judicial interpretation even more important. This triple interaction could be referred to as the "paradox of international adjudication": more demand for treaty interpretation given ambiguity and rigidity of treaties; yet, less supply of treaty interpretation given the reluctance of states and (more often than not) tribunals to judicially deal with highly contested questions between sovereign states (sensitivity of treaties).

International law does offer "general rules" for interpreting treaties. These rules are set out in Articles 31 to 33 of the VCLT and reflect customary international law binding on all states. The VCLT offers two main principles. The first is that treaties must be interpreted "in good faith" in accordance with the "ordinary meaning" of the "terms" or text of the treaty, in their "context", and in light of the treaty's "object and purpose". This summing up of text, context and purpose is described as a holistic, non-hierarchical exercise, albeit one that starts with the text of the treaty (Abi-Saab 2010). The VCLT's second main principle is that the "preparatory work of the treaty and the circumstances of its conclusion" are only secondary sources of interpretation, to confirm meaning established under the first principle or in case the meaning of the treaty remains unclear or leads to an absurd result. 
As general rules, these VCLT rules apply to all treaties, irrespective of the subject matter, goal or number of parties to the treaty. If states so wish they can contract out of these general rules by including specific rules in a particular treaty. If no special rules are provided (which is the case for most treaties), the general VCLT rules apply. This said, there is general agreement that the application of these VCLT rules, in any particular case, leaves ample scope for manoeuvre and allows different tribunals to prioritize different interpretative methods or elements (e.g. text, context or purpose). Indeed, the VCLT rules themselves are a result of negotiations and are ridden with ambiguities. Therefore, when, for example, a WTO panel must interpret a WTO treaty provision it is, in effect, giving meaning to one incomplete contract (the WTO treaty) using another incomplete contract (the VCLT) as guidance. In addition, the VCLT rules, though generally applicable, are not necessarily exhaustive and, other additional principles or guidelines may exist or can develop, as part of customary international law or within specific treaty regimes. This gives international tribunals additional flexibility.

IL scholars have been debating for decades which interpretative method is most appropriate, some agreeing with the VCLT rules and others vehemently opposing them (McDougal 1967). Our goal is not to add to this debate by arguing that this or that technique is normatively better. Instead, we want to enter the black box of judicial discretion left to international tribunals when they apply the VCLT rules. When exercising the wiggle room left to them under the VCLT, what directions have courts taken, and how do these directions differ over time and between international tribunals? To the extent we see variance, what factors may explain it?

As to the importance of treaty interpretation two caveats apply. First, our claim is not that treaty interpretation is always the crucial factor in the outcome of disputes. In some cases, the tribunal's establishment of the facts rather than the law is more important. Second, although we believe that a tribunal's stated method of interpretation influences outcomes (especially where a court's discretion is bound by a particular method selected by earlier courts), we do acknowledge that in some cases a tribunal's interpretative method may be little more than an ex post justification or "façade" for an outcome reached on other grounds (Lauterpacht 1949). In these cases, the impact of the five interpretation choices we identify below is undoubtedly diminished. Yet, even (and perhaps especially) in these cases, our explanatory framework (Part IV) remains important: the factors we identify there are exactly the 
types of "other grounds" (in this case, grounds other than methods of legal interpretation) that may explain a tribunal's decision. The discussions and deliberations among tribunal members take place out of the public eye. This is a strategic advantage which court members are well aware of and want to preserve. They may (or may not) want to provide specific clues in an attempt to sustain their informational advantage. They might at times leave observers and scholars in the dark about their true intentions. Therefore, paradoxical situations can evolve. For instance, agents anticipate that "poorly justified decisions tend not to have extensive impact" (Ferejohn 2002:54). Therefore, they may abstain from explaining to the public how their decision was driven by interpretation. This makes the task of systematising and analysing treaty interpretations more complex than many other types of policy outcomes. This said, even where a stated interpretative choice is merely a façade it remains worthy of study "since at the very least it represents an effort at selfconscious public justification" that "enables us to understand what are regarded as satisfactory and publicly acknowledgeable grounds for decision making" (Bankowski et al 1991:17).

\section{INTERPRETATION CHOICES}

How should the International Court of Justice (ICJ) interpret Costa Rica's right to free navigation on the San Juan River "con objetos de comercio"? For Nicaragua, which was taxing Costa Rican tourists on the river, these Spanish terms in an 1858 treaty between the two countries are limited to free transport of goods. In contrast, for Costa Rica, which has a booming tourist industry, "con objetos de comercio" covers the free transport of both goods and passengers including tourists. Similarly, when the WTO treaty states that import duties to offset subsidies provided in the country of production must be imposed "in the appropriate amounts in each case" does this prohibit the imposition of such duties together with duties to offset dumping? Finally, where a provision is silent on the question, does the International Criminal Tribunal for the Former Yugoslavia (ICTY) have jurisdiction over offences committed in internal armed conflict or only those committed in international armed conflict? The above examples indicate how common and important questions of treaty interpretation before international tribunals can be. Opt for one interpretation and the 
claimant wins; opt for the other, and the defending country or person is left untouched.

How then do international tribunals make their choice? As noted above, the VCLT rules do impose a general framework, but within this framework, a certain degree of discretion remains. Below we offer a taxonomy of the most important and most commonly discussed choices of interpretation techniques that tribunals must select from. Obviously, this is not by any means an exhaustive list. We have only picked a limited number of variations, focusing on the major, commonly practised and discussed ways of interpreting treaty texts. Although there may be overlaps and interactions (as discussed below), these five variables generally operate independently so that, technically, tribunals may have five different choices to make.

Once the main strands or variations in treaty interpretation are identified, a serious problem arises when it comes to identifying an international tribunal with one or the other technique. Although some tribunals have been more consistent than others, in many cases, the same tribunal may stress one technique in one case, but another in the next. Also, within the same tribunal, one judge may push for one technique, whereas another judge goes for an opposing method. As a result, there may be as many interpretative choices as there are cases to decide. This said, certain generalizations can be made. When we do so below, we will base them on the general views of scholars rather than make our own claims. Most courts have central tendencies and generally prefer certain types of interpretation over others. Yet, variance can also be observed over time, e.g. comparing early cases of the WTO Appellate Body (AB) with cases decided 15 years after its creation. Finally, the same tribunal may opt for one method when it comes to one set of cases, but select another method for another type of dispute (think of the European Court of Human Rights interpreting torture cases differently than cases on freedom of speech (Letsas 2010:510), or the ICJ using different methods of interpretation for unilateral declarations or UN Security Council Resolutions than for treaty interpretation (Gordon 1965; Orakhelashvili 2008)).

\section{The dominant hermeneutic: text, party intent or underlying objective?}

The first distinguishing feature we observe relates to the guiding principal or substantive benchmark that a tribunal sets for itself when giving meaning to a treaty. 
Three broad types of dominant hermeneutic can be detected: in case of doubt, will the tribunal rely primarily on (i) the text of the treaty, (ii) what the parties to the treaty intended, or (iii) the underlying objective that the treaty seeks to attain? As noted earlier, the VCLT refers, in one way or another, to all three elements. When applying VCLT rules, however, a tribunal can be guided more by one element (say, text) than the other (for example, objective).

Most interpreters agree that the task bestowed upon them is to give effect to the intentions of the parties. In this sense, tribunals are the agents of the state parties (principals) who created the tribunal. Yet, the next question is where a tribunal must look to find this intention of the parties? The first approach is to say that the best and most objective expression of intent can be found in the treaty text itself (Fachiri 1929). The second approach is to argue that text is but one element and that the interpreter needs to dig deeper to uncover the actual, subjective intentions of the parties, e.g., by looking at the preparatory works of a treaty (Lauterpacht 1950; McDougal et al. 1967). The third approach is to focus not so much on the raw text of the treaty or the subjective intentions of the drafters themselves, but on the underlying objectives these drafters were attempting to achieve (the so-called teleological approach, Crema 2010:512). Thus, a tribunal's guiding star or dominant hermeneutic can be text, party intent or objective.

The differences between these three approaches are not trivial. A textual approach will give meaning to words, for example, by looking these words up in a dictionary and trying to give the words, as they are used in a particular context, their "ordinary meaning". In so doing, the interpreter will tend to refer to common understandings amongst a relatively broad group of people (e.g. those reading and understanding English). In contrast, if party intent is a tribunal's guiding star, the interpretative community tends to be narrowed down to the more limited group of drafters actually involved in the treaty-making process. This subjectivity - referring, for example, to shared expectations or values of the drafters (rather than the meaning of words) - has been said to (further) open the door for judges to yield to the preferences of the most powerful actors involved. For example, relying on the negotiation history of the WTO treaty is likely to yield more statements by the United States, the EU or Canada, than to reflect the views of Malawi or Paraguay, let alone Oman or Taiwan which only joined the WTO after its establishment. Finally, if a tribunal's guiding star is the underlying objective of the treaty, interpretation can take 
account of a broader interpretative community, beyond the original state parties as such, and rapidly becomes value-based, e.g. in favour of the protection of human rights, of investors or of free trade. Meaning is then given to the treaty with less reference to the linguistic meaning of words or subjective intent of the drafters and more with the spirit of the treaty in mind, in an attempt to give maximum effect to the treaty's underlying normative values. As pointed out above, such value-based interpretation is probably the interpretative method that risks the most fragmentation or conflict between tribunals: if investment tribunals interpret pro investors; human rights tribunals interpret pro homine and WTO tribunals construe pro traders, the risk of inconsistent outcomes is higher.

International tribunals that have commonly been placed in the textual school are: the WTO AB, the ICJ and the International Criminal Court (ICC). One member of the $\mathrm{AB}$, who also served as a judge on the ICTY and the ICJ, went so far as to call the WTO AB an "obsédé textuel" (Abi-Saab 2010:106). An ICC observer states: "If legality is recognized as the guiding principle for interpreting crimes in the Court's jurisdiction [see Article 22.2 of the ICC Statute providing that the definition of a crime "shall be strictly construed"], it would require the textual approach to prevail over competing intent as well as object and purpose based approaches" (Grover 2010:557). Although the dominant hermeneutic of the ICJ is less outspoken, the conventional view is that, if anything, the ICJ's method of interpretation is more textual than intent or objective based. One author concluded, for example, that "the I.C.J. usually gives excessive primacy to the textual element without combining it with other elements of the general rule" (Romani 2007:156).

Examples of tribunals that follow party-intent as their dominant hermeneutic are more difficult to find, if only because the VCLT explicitly demoted preparatory works to the class of secondary sources. One example is GATT panels which operated before the establishment of the WTO in 1995. As Howse describes: "Traditionally, under GATT, resort to the travaux constituted a pervasive and largely uncontroversial interpretative practice" (Howse 2000:57). Confirming the existence of a relatively small interpretative community, centred around the subjective intentions of the original GATT drafters, acceptance of a GATT panel ruling was a function of "a ruling's consistency with the general consensus among the trade policy élite" (Howse 2000:57). Indeed, it is this subjective interpretation, with reference to preparatory works, which led the drafters of the WTO treaty (which succeeded the GATT) to 
explicitly include a reference to VCLT rules of interpretation. This was done to steer WTO panels towards a more "objective", text-based interpretation (Kuijper 1994). Another example where frequent reference is made to the intentions of the parties is arbitration, including investor-state arbitration, where the principle of "party autonomy" is pervasive (especially in commercial arbitration) (Schreuer 2010:138).

Finally, examples of international tribunals that have favoured a teleological approach are: the European Court of Justice (Lenaerts 2007), European and InterAmerican Courts of Human Rights (Letsas 2010:512; Lixinski 2010:588), the International Criminal Tribunals for Yugoslavia and Rwanda (Swart 2010:770; Schabas 2003) and, albeit to a lesser extent, investor-state arbitration (Schreuer 2010:131; Fauchald 2008:316).

\section{Timing: original or evolutionary interpretation?}

A second, major interpretative choice that international tribunals face relates to timing. When the ICJ interprets the term "commerce" in the 1858 treaty between Costa Rica and Nicaragua referred to earlier, does it take the meaning of that word in 1858 , when the treaty was concluded, or its meaning in 2009 when the ICJ had to interpret the treaty? If 1858 is chosen, Costa Rica's claim for free navigation of tourists would probably be rejected, as at that time there were no tourists on the river. If 2009 is picked, Costa Rica most likely wins. Similarly, when the WTO AB must give meaning to the words "exhaustible natural resources" (which can be protected by trade restrictive measures under GATT Article XX), is it to pick the prevailing meaning in 1947 (when the GATT was concluded) or that in 1998 when it decided the famous US - Shrimp dispute? In 1947, when the terms were written, drafters had minerals in mind (whose exportation could be restricted to conserve "exhaustible natural resources"). In 1998, when the Shrimp dispute arose, the United States imposed an import ban to protected endangered sea turtles which, in its eyes, were also "exhaustible natural resources".

The above-explained VCLT rules are silent on this question of timing. Unlike the first variation discussed earlier - focused on what it is that the tribunal takes as its guiding star (text, intent or purpose) - this second variation asks at what point in time or when the interpretation must take place: contemporaneous with the date of 
conclusion of the treaty (original interpretation) or evolving over time and set at the time of deciding a dispute (evolutionary interpretation).

Much like the first variation (what), this second variation (when) has major consequences. If an evolutionary interpretation is chosen, Costa Rica wins the ICJ case; in the WTO dispute, the United States can rely on an exception. The importance of this interpretative choice is further highlighted by what we referred to earlier as the rigidity of treaties. Given the consent rule, treaties can normally only be amended or adjusted to new developments if all parties to the treaty so agree. As a result, the more parties to a treaty the more difficult it becomes for treaty-makers to adjust it. This puts the burden on an international tribunal to either do this "legislative updating" itself, or to refuse to do so but risk becoming less relevant as an adjudicator.

Examples of tribunals taking an evolutionary approach and interpreting treaties as "living instruments" are: the WTO AB (Van Damme 2009) and the Inter-American and European Courts of Human Rights (which commonly apply moral and societal views of the day updated since the conclusion of their respective treaties, be it on questions of abortion, divorce or homosexuality) (Letsas 2010:527). Examples of evolutionary interpretation can also be found in investor-state arbitration (Schill 2010). In contrast, international tribunals opting for a static or original approach are: the International Criminal Court (which can only hold someone responsible if the conduct constituted a crime at the time it took place, not with reference to the date of the tribunal's decision (Grover 2010; Okowa 2010:351), so-called Claims Tribunals set up to decide on reparation claims in the context of particular past events (Caron 2007:405) and, at least to some extent, GATT panels (focused on the intention of the drafters as expressed in 1947) (Howse 2000). The ICJ, in contrast, falls somewhere in between, at times taking an evolutionary approach (as in the Costa Rica v. Nicaragua case discussed earlier), in other cases opting for a static or original interpretation. To decide on which approach to take in a particular case, the ICJ examines the implied intentions of the parties to the treaty, finding that they can be presumed to have chosen an evolutionary approach if they have used "generic terms" and concluded the treaty for an indefinite period of time (Milanovic 2009).

When this second, time-related variation (original vs. evolutionary) is put together with the first, benchmark-related variation (text, intent, purpose), it is clear that any tribunal can select its own particular combination. Confirming that the two sets of variations do deal with different questions, a tribunal can be textual and 
evolutionary (such as the WTO), but also textual and originalist (such as the ICJ in some cases). A tribunal whose dominant hermeneutic is party-intent is more likely to be originalist (looking for the subjective intent and meaning in the minds of the drafters when the treaty was concluded; as was arguably the case with GATT panels), but can also be evolutionary (if party-intent indicates that the parties wanted treaty terms to evolve over time, as in some of the cases decided by the ICJ). This said, a tribunal which has as its guiding star the underlying objective of the treaty (teleological interpretation) is likely to update its interpretation of the treaty with reference to new developments. In that sense, teleological and evolutionary interpretations go hand in hand.

\section{Activism: work to rule or gap-filling approach?}

A third fundamental variation we observe is between tribunals that take a deferential, strict constructionist or work to rule approach, and tribunals taking a more activist, gap-filling approach. Although some overlap exists, this third variation is fundamentally different from the first (text, intent or purpose-based interpretation). Whereas the first variation relates to what the tribunal sets as its guiding star or dominant hermeneutic (does it look at the text, try to uncover party-intent or is it guided by the underling purpose of the treaty?), this third variation says something about how the tribunal construes its own role or function, irrespective of what it has chosen as its guiding principle: is the function of the tribunal to apply only what the treaty (text, intent or purpose) provides for; or is it the task of the tribunal also to push the envelope and complete the contract where appropriate or fill gaps in the treaty as they are discovered in the judicial process?

The work to rule approach tends to favour defendants, as tribunals defer to the sovereignty or presumed innocence of the party whose obligations are assessed. In case of doubt, the tribunal will find no obligation. Where the treaty does not (explicitly) cover a matter, the tribunal will find no violation. In contrast, where a tribunal is ready to fill gaps, even if the treaty does not explicitly regulate a question, the tribunal (based on text, intent or purpose) will construe an applicable rule. Such gap-filling can work either way (in favour of the defendant or of the complainant). What matters is that tribunals take on a role which according to some ought to be reserved to the legislator. According to others, gap-filling is exactly what courts must 
do, as anti-majoritarian devices to guarantee individual rights against government (including majority-approved) abuse. Looked at from a different angle, the spectrum of activism of tribunals has, at one extreme, work to rule tribunals that are simply "work to rule" agents, completely differential to the views and action of the treatymakers. At the other extreme, we find activist, gap-filling courts that are quite "selfconfident" agents operating largely independently of the parties that made the treaty and established the tribunal.

It is notoriously difficult to determine the level of activism of a court. Obviously, parties whose preferred interpretation was rejected by a tribunal tend to argue that the tribunal got it wrong and that it engaged in impermissible activism. The other side, of course, will take the view that the tribunal's interpretation is exactly what the parties intended and that no judicial activism took place. This said, and at the risk, once again, of making overly general conclusions, the following tribunals are often described as activist or gap-filling: the European Court of Justice (Rasmussen 1986) and European and Inter-American Courts of Human Rights (Letsas 2010:518). Because of its Statute, the ICC, in contrast, is, at least at this early stage, best qualified as a deferential or work to rule tribunal (Grover 2010:556). Other courts are more difficult to classify. Although the WTO AB was generally described as cautious and deferential in its early years (Howse 2000), in more recent years it has taken a more activist stance (Steinberg 2004). Similarly, whereas the ICJ in its earlier case law often took a deferential or pro sovereignty approach, it has recently opted for a more neutral assessment (interpreting treaties neither restrictively nor expansively) (Milanovic 2009). When it comes to investor-state arbitrations, the substantive principles involved are few and broadly defined (e.g. obligation to offer "fair and equitable treatment") so that some degree of gap-filling is inevitable. At the same time, few, if any, cases can be pointed to where tribunals engaged in gap-filling beyond the principles provided for in the treaty. Whereas some tribunals have taken a deferential stance in favour of host countries and others a more activist approach in favour of investors, the most recent trend is for tribunals (very much like the ICJ) to take a neutral position (no presumptions either way) (Roberts 2008).

\section{Case-by-case analysis or rule of precedent?}


A fourth important variable we observe is the extent to which a tribunal decides every case de novo, without reference to previously decided disputes or, instead, relies on precedent, accepting earlier decisions either as legally binding or persuasive guidance. In a case-by-case approach, earlier interpretations do not bind or guide a tribunal and every dispute is decided afresh on its own merits. This means that the parties are fully in control and need not worry about precedents. It also means that there is no (or less) need to get involved in other disputes as third parties so as to avoid or steer precedents that may one day affect one's own case. Where weight is given to precedent, in contrast, a normative regime develops, which is composed not only of the treaty as such but also of previously decided cases (in the ECJ context, referred to as the acquis communautaire).

Although judicial decisions are referred to as one of the (secondary) sources of international law in the ICJ Statute, the VCLT rules are silent on the interpretative role of earlier judicial decisions. Only one international tribunal that we know of (Caribbean Court of Justice) follows a rule of legally binding precedent. Yet, most other tribunals, to some extent, do refer and rely on earlier decisions (by the same or another tribunal) (Jacob 2011). For some international tribunals, the weight to be given to earlier decisions is explicitly provided for (ICC Statute, Article 21.2). In other cases, reliance on precedent developed de facto. Fauchald finds, for example, that 92 of 98 investor-state tribunals (that is, 94\% of cases between 1998 and 2006) refer to prior awards. At the same time, he does add that "the extent to which ICSID tribunals in general felt free to criticize and deviate from the findings in previous case law was remarkable" (Fauchald 2008:338). In other words, there is a difference between referring to precedent and generally feeling bound by it, as in the ICJ (Ginsburg 2005:7; Rosenne 2006:1555) and even more so in the WTO (David 2009), and referring to earlier decisions and then going your own way (as is commonly the case for investor-state arbitrations or often happened in the GATT).

A further distinction that can be made is between reference back to cases decided earlier by the same tribunal (e.g. the ICJ referring to an earlier ICJ judgment) or to a higher court within the same system (e.g. a WTO panel referring to an earlier $\mathrm{AB}$ ruling), as opposed to one tribunal making reference to another tribunal in an entirely different system or regime (say, the ICTY or the WTO AB referring to the ICJ or vice versa). Although there is no formal hierarchy between international tribunals, de facto, judgments by the ICJ ("the principal judicial organ of the UN") are 
quite often referred to by specialized tribunals (Rosenne 2006:1555). Interestingly, however, in more recent times, the reverse has also been happening: the ICJ referring back, for example, to an earlier WTO AB report or ruling by the ICTY/ICTR (Payne 2010).

\section{Linkage: self-contained or systemic interpretation?}

The fifth, and final, interpretative choice relates to how international tribunals position themselves in relation to the outside world, in particular, their linkage to other treaties and tribunals. Some tribunals construe their universe as a self-contained regime that is purely inward looking. In the process of treaty interpretation, they limit themselves to the four corners of their constitutive treaty and the legal instruments enacted within their regime. Pre-1995 GATT panels, for example, limited themselves to the GATT and only in exceptional circumstances did they refer to general international law (including, for that matter, the VCLT) or branches of international law other than trade law (e.g. international environmental agreements) (Howse 2000). In addition, self-contained tribunals will not normally refer to rulings of other international tribunals.

In contrast, other international tribunals are outward-looking and interpret their constitutive treaty with reference to general international law and other treaties. In so doing, they strive for a systemic interpretation that attempts to reconcile different treaties and read international law as a coherent system of law (rather than a collection of self-contained regimes). Whereas the GATT was largely inward looking, one of the major transformations that occurred with the establishment of the WTO was the openness of the WTO AB to other rules of international law. Moving away from what it called "clinical isolation", the AB has gradually constructed the WTO treaty in the broader context of other treaties and general international law. In so doing, the AB has

referred not only to VCLT rules and general international law principles on burden of proof, proportionality or state attribution, but also to environmental agreements, customs treaties and regional trade agreements (Pauwelyn 2003). Indeed, when it comes to VCLT rules, more than any international tribunal (and certainly more so than the ICJ), the WTO AB has, in almost every case, explicitly referred to them. In addition, more than any other court, it applies VCLT rules to the letter, in many cases going through each and every element or interpretative guideline referenced in the 
VCLT (Abi-Saab 2010). More recently, however, this formalistic trend has declined and the $\mathrm{AB}$ has reduced its formal attachment to each of the steps of treaty interpretation in the VCLT (Van Damme 2009).

The ICJ, in contrast, as a court of general jurisdiction (states can, technically, send cases to it on any subject matter) has from the start been more outward-looking. At the same time, when it comes to explicitly referring to VCLT rules on treaty interpretation, the ICJ was, somewhat paradoxically, one of the last tribunals to do so (Torres Bernardez 1998:721). Nor has the ICJ traditionally spent a lot of time explaining its interpretative approach or gone through the VCLT steps of treaty interpretation in any great detail. A recent trend has been detected, however, where the ICJ refers more explicitly and in more detail to VCLT rules (Gardiner 2008:14).

Investment tribunals generally have broad powers in terms of the law they can apply to resolve a dispute (domestic law, the bilateral investment treaty that grants them jurisdiction and other rules of international law). Yet, somewhat surprisingly, in the process of treaty interpretation, investment tribunals have been reluctant to refer to outside treaties (Hirsch 2009) (more so, for example, than the WTO AB even though the WTO treaty does not explicitly incorporate other international law as part of the applicable law to resolve WTO disputes). Moreover, only recently have investment tribunals started to explicitly and commonly refer to VCLT rules on interpretation (Gardiner 2008:xxxi). Investment tribunals also increasingly refer to PCIJ/ICJ rulings (Fauchald 2008:343), while at the same time expressing a general reluctance to incorporate ideas of international trade law or WTO jurisprudence (although that trend may be changing) (DiMascio and Pauwelyn 2008).

The European Court of Human Rights, though it does not often refer to VCLT rules when it interprets (Letsas 2010:513) (as noted above, it pursues more of a teleological interpretation), has resolutely chosen to take an outward-looking, systemic approach to interpretation. In so doing, it construes the ECHR with reference to general international law as well as to other treaties. A similar approach is taken by the IACHR (Lixinski 2010:603). The ECJ is a special case in this respect, especially as it is gradually coming closer to being a domestic rather than a truly international tribunal. Some authors, however, have described an evolution within the ECJ from being a court relatively open to other international law to one that is increasingly closed (Kuijper and Bronckers 2005). 
A different type of outreach or linkage where variance between tribunals can be detected relates to the extent to which tribunals refer to academic writings in the process of giving meaning to a treaty. This may come as a surprise to other academics, but under international law "the teachings of the most highly qualified publicists" are listed as a supplementary source of international law (ICJ Statute, Article 38:1(d)). At the same time, very much like precedent, VCLT rules do not make any reference to academic writings as an interpretative tool. In the WTO, for example, notwithstanding the increasing number of academics focusing on WTO law, panels and, even less so, the WTO AB, hardly ever refer to academic writings. If they do so, it is, moreover, most likely to be a reference to relatively old publications on general international law and not to writings on GATT or WTO law (Van Damme 2009). In addition, even the parties to a WTO dispute hardly ever refer to the multitude of academic studies on WTO law.

In contrast and, like most of the variance described above, notwithstanding the fact that the same VCLT rules generally apply, investment tribunals frequently refer to publicists (in Fauchald's study, in 73 out of 98 decisions examined (Fauchald 2008:352)). When it comes to the PCIJ/ICJ, one of its most astute observers writes: "both Courts are very reticent in direct citation of named publicists in support of any proposition of law". Yet, "[w]ritings of publicists and of members of the Court are frequently quoted in pleadings, and in individual and dissenting opinions" (Rosenne 2006:1558).

The five interpretation choices discussed above, with illustrative examples of variance between international tribunals, are summarized in table 1. 
Table 1: Overview of Interpretation Choices

\begin{tabular}{|c|c|c|}
\hline $\begin{array}{c}\text { Interpretative } \\
\text { Choice }\end{array}$ & Options & Examples \\
\hline $\begin{array}{c}\text { DOMINANT } \\
\text { HERMENEUTIC }\end{array}$ & $\begin{array}{l}\text { Text: linguistic meaning; relatively broad interpretative } \\
\text { community } \\
\text { Intent: more subjective; closer community of drafters } \\
\text { Objective: value-driven, prone to fragmentation }\end{array}$ & $\begin{array}{l}\text { Text: WTO AB, ICC, ICJ } \\
\text { Intent: GATT panels, ad hoc } \\
\text { arbitration } \\
\text { Objective: ECJ, ECHR, } \\
\text { IACHR, ICTY, ICTR }\end{array}$ \\
\hline TIMING & $\begin{array}{l}\text { Original: meaning at the time the treaty was concluded } \\
\text { (static, frozen in time) } \\
\text { Evolutionary: meaning at the time the dispute is } \\
\text { decided (dynamic, evolves with new developments), } \\
\text { addresses problem of treaty rigidity }\end{array}$ & $\begin{array}{l}\text { Original: ICC, Retrospective } \\
\text { Claims Tribunals, GATT } \\
\text { panels } \\
\text { In between: ICJ } \\
\text { Evolutionary: WTO AB, } \\
\text { ECHR, IACHR, ECJ }\end{array}$ \\
\hline ACTIVISM & $\begin{array}{l}\text { Work to rule: deferential, strict constructionist often in } \\
\text { favour of defendant; tribunals as work to rule agents } \\
\text { Gap-filling: legislative function, tribunals as self- } \\
\text { confident agents completing the contract }\end{array}$ & $\begin{array}{l}\text { Work to rule: ICC, GATT, } \\
\text { early WTO AB } \\
\text { Gap-filling: ECJ, } \\
\text { ECHR/IACHR, later WTO AB }\end{array}$ \\
\hline PRECEDENT & $\begin{array}{l}\text { Case-by-case: no or less weight given to earlier rulings; } \\
\text { settles dispute between the parties only; little or no } \\
\text { impact on third parties } \\
\text { Precedent: earlier rulings complement normative } \\
\text { framework; third parties are affected, de facto binding }\end{array}$ & $\begin{array}{l}\text { Case-by-case: GATT, (to } \\
\text { some extent) investor-state } \\
\text { arbitration } \\
\text { Precedent: Caribbean Court of } \\
\text { Justice, ECJ, WTO AB, ICJ, } \\
\text { ECHR/IACHR }\end{array}$ \\
\hline LINKAGE & $\begin{array}{l}\text { Self-contained: inward-looking, reference to own legal } \\
\text { instruments only, prone to fragmentation } \\
\text { Systemic: outward-looking, links to general } \\
\text { international law (including VCLT) and other treaties } \\
\text { and tribunals; academic writings }\end{array}$ & $\begin{array}{l}\text { Self-contained: GATT panels, } \\
\text { (more recently) ECJ } \\
\text { Systemic: ICJ, WTO AB, } \\
\text { (more recently) investor-state } \\
\text { arbitration, ECHR/IACHR }\end{array}$ \\
\hline
\end{tabular}

\section{EXPLAINING VARIATION IN INTERPRETATION}

Above we presented our conceptualization of five types of interpretation. We now turn to explanations. Why is it, for example, that an international tribunal opts for evolutionary rather than original interpretation? How can we explain that GATT panels focused on party intent (including the travaux préparatoires of GATT) and were largely inward-looking, work to rule agents, whereas the WTO AB focuses on text and adopts an outward-looking, systemic method of interpretation? In this section, we develop an initial framework of analysis. We suggest that variation of interpretative methods across tribunals is not randomly distributed. Members of tribunals do not toss a coin to decide which approach to take. We realize that the factors we list below are not exhaustive and sometimes overlap. Still, we believe that the framework captures the essential drivers and offers a useful way to distinguish between them. 
We suggest that interpretation choice is a result of the interaction of two key variables: (i) the demand side interpretation space that is made available to a tribunal and (ii) the supply side interpretation incentives defined as intrinsic motivations of a tribunal's members when operating within this space. Interpretation space, in turn, is defined by degree of contract incompleteness and principals' ability to overcome collective action problems. Interpretation incentives, finally, are conditioned by institutional factors and existing norms. Figure 1 provides an overview of the causal set-up of our framework.

Figure 1. General Framework for Explaining Interpretation

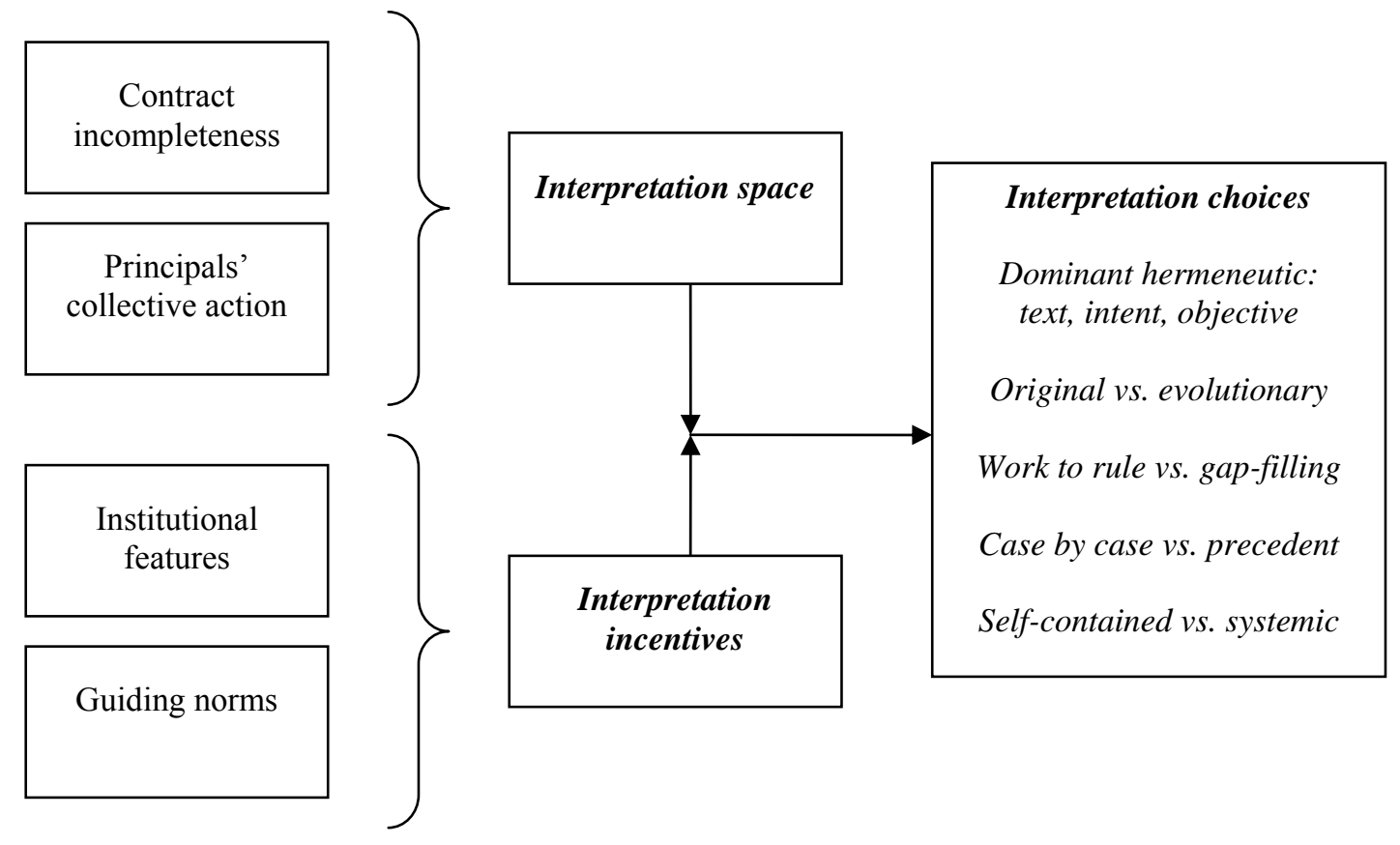

\section{Interpretation Space}

The starting point for treaty interpretation is the demand side, in particular the interests of states as principals. These interests (and their impact) are reflected in the degree of contract incompleteness and states' ability to act collectively.

\section{Contract Incompleteness}

The literature on incomplete contracts defines interpretation as part of a tribunal's contribution towards maximizing ex post contract performance. How much a tribunal is asked to interpret is defined by (i) the degree of guidance established in the contract 
(interpretative aids, how to deal with uncertainty) and (ii) the clarity and precision of obligations (little ambiguity requires less interpretation).

As to overall guidance, for some international tribunals (e.g. the ICC or WTO) the treaty stipulates explicit rules on how to interpret. This offers a first important means for treaty drafters to influence interpretation space: by stipulating precise interpretation rules, drafters can guide treaty interpretation. The strict constructionist guidance in Article 22 of the ICC Statute is said to be a response to the "perceived liberal interpretative reasoning of the ad hoc [ICTY and ICTR] tribunals" (Grover 2010:553). The direction in the DSU to follow the "customary rules of interpretation of public international law", that is, VCLT rules, was provided to correct certain interpretative practices of GATT panels. Unlike GATT panel practice, these VCLT rules put text before travaux préparatoires and call upon an interpreter to give meaning in the context of the broader field of international law. Most tribunals (and especially ad hoc tribunals) lack any explicit guidance (e.g., investor-state arbitrations).

In terms of clarity and precision of obligations (the second factor in contract incompleteness), we may witness important differences between treaties. Some treaties can set out very precise rules (e.g., tariff reductions in trade agreements). Others (such as human rights or investment agreements) may be limited to general principals or standards. Similarly, some treaties are more akin to contracts concluded at arm's length (so that the intentions of the parties may be an appropriate benchmark for interpretation). Others are more like legislative or even constitutional documents (where reliance on a broader interpretative community and treaty objectives may be more appropriate) (Weiler 2008). The more general the obligation, the more demand for interpretation in ex post contract performance. If normative prescriptions resemble rules (say, a maximum customs duty of $5 \%$ on a given product) than we expect less need for interpretation. If prescriptions are in the form of standards (say, no inhumane punishment or unfair treatment of investors), states increase the degree of delegation to international tribunals (Abbott et al 2000). The use of generic terms increases incompleteness and pushes international tribunals to adopt an evolutionary rather than an original interpretation. Because treaty terms are ambiguous, and generic treaty terms often remain in place, un-amended for decades, international tribunals (e.g. the $\mathrm{AB}$, the ECHR/IACHR and, increasingly also, the ICJ) are inclined to update the treaty through evolutionary interpretation. Treaty incompleteness, both at origin and 
increasing over time, can also explain a tribunal's interpretative choice on the activism scale discussed above (work to rule vs. gap-filling): the more incomplete a treaty is, the bigger the mandate or temptation to fill gaps. The ECJ (Arnull 2006:621) and ECHR/IACHR (Lixinski 2010:589) have, for example, been relatively activist; not because of some dark conspiracy amongst judges, but because of the inherent vagueness and nature of their constituent treaties.

\section{Principals' collective action}

We suggest four specific factors that reflect or determine collective action on the principals' side: function, saliency, competition and control.

First, the interests of principals can be captured by the expectations as to the function of a tribunal. These range from making credible commitments (Helfer and Slaughter 2005), addressing reneging or opportunistic behaviour (Alter 2008b), efficient decision-making and settling disputes, to constraining powerful states (Grant and Keohane 2005), avoiding escalation (Davis 2011), representing powerful states in ex post contract performance (Posner and Yoo 2005), and ensuring constitutional checks and balances, including against majoritarian decisions (McGinnis and Movsesian 2000). One and the same tribunal may contribute to several of the above functions. Principals' interests as to the exact function in turn determine interpretation space. For example, ad hoc tribunals deciding on past events, whose core function is to settle specific claims or disputes (retrospective tribunals with a fixed docket), have less interpretation space than, for example, the ECHR or WTO AB whose function is (also) to clarify agreements and develop predictable rules with a much longer time horizon (prospective tribunals with an open-ended docket). We also expect retrospective tribunals with a fixed docket to be more inclined to opt for an original interpretation (so as to ensure equal treatment of all claims), whereas prospective tribunals with an open-ended docket will be more likely to interpret treaties in an evolutionary manner (so as to update the treaty to reflect new developments over time). Finally, where a core function of the international tribunal is to develop a consistent and predictable set of rules (as in the WTO) the tribunal will be more inclined to give weight to precedent rather than to decide each case de novo.

Second, whether principals' interests translate into influence depends on the extent to which principals and the broader community care about the outcomes of courts (saliency). If there is low saliency, courts get more interpretation space. In the 
EU, for example, scholars have demonstrated that the activism of the ECJ was largely unexpected. Over time, however, as Member States became aware of the nature and stakes of ECJ activism, they increased their efforts to influence, and in some cases overturn, unwelcome judicial decisions (Mattli and Slaughter 1998). Low saliency may also explain some of the activist pro-trade decisions made by early GATT panels given that, in its early decades, GATT was seen as a largely technical, customs-only organization, hardly reaching the political headlines. Similarly, activism detected in certain (early) investor-state arbitrations may be explained by low saliency, i.e., the fact that some of these early cases were decided behind closed doors and litigated between technical experts, with higher level officials and the public not being in the loop. The same can be said about the ICTY/ICTR (attracting little attention from principals) compared to the ICC (higher saliency, partly because of ex post awareness of the impact of ICTY/ICTR activity).

Third, competition between principals affects collective action. From the principal-agent literature we have learned that the existence of multiple principals affects overall discretion of the agents (or interpretation space in our case) (Nielson and Tierney 2003). If divergence of interests among principals increases, new autonomy will open up for judicial agents or, as John Ferejohn put it, "Courts and agencies are capable of independent or autonomous action where the constitutional legislature is too fragmented to react" (2002:63). This is a crucial insight which may explain the WTO AB's more recent activism. Whereas at the time of its creation in 1994, the WTO was controlled by a handful of countries (especially the EU and the US), in more recent years multiple powerful actors have emerged (including China, Brazil, India and South Africa). This interest divergence increases the interpretation space, and in turn, enables the $\mathrm{AB}$ to be more activist, knowing that its rulings may upset some powerful countries but please others. Steinberg argues that "WTO dispute settlement could assume a new form as a result of fundamental changes in the political environment, such as the dispersion of power at the WTO or a divergence of interests of powerful states. If either shift were to occur, the strategic space for judicial lawmaking at the WTO would expand, as it would become more difficult to establish and sustain the political cooperation necessary to check or correct $\mathrm{AB}$ action" (2004:275).

Fourth, collective action depends on control. Principals have different sets of ex ante and ex post control tools by which they can influence interpretation space. Ex 
ante control predominantly functions through the selection of judicial agents. There is no lifetime appointment in international tribunals. Appointments vary between fixed terms for standing bodies (with the possibility of renewal and with or without a compulsory retirement age) and ad hoc short-term appointments, e.g. for GATT or WTO panels and investor-state arbitrations. Where adjudicators are appointed ad hoc, we expect them to be under closer control by the parties (their interpretation space shrinks) and hence they are more likely to opt for party-intent as the dominant hermeneutic and adopt a more deferential, less activist approach. Fixed term appointments, on the other hand, would lead to the opposite conjecture. Appointments also differ as a function of the composition of tribunals. Attention (politicization) tends to be less in the case of a representative court (e.g., ECJ/ECHR; all members can nominate a judge and other parties tend merely to rubber stamp each others' selection) (Voeten 2007 or Voeten 2008) than with a selective court (seats are limited and all parties have a say on all selections, as for the WTO AB and, somewhat less so, the ICJ) (Elsig and Pollack 2011). Ex ante control may change over time. In the WTO, its Members, in the face of a more activist AB, seek to enhance ex ante control (Elsig and Pollack 2011). In investor-state arbitrations, where each party appoints one of the three arbitrators, the divide between investor-appointed and state-appointed adjudicators has widened. Arbitrators increasingly belong in one or the other camp, and are appointed accordingly, with certain expectations as to interpretative choice and outcome. In many cases, this constellation gives the deciding vote to the neutrally appointed president of the tribunal and, in turn, increases the tension and control over presidential appointments.

Ex post control relates to whether principals can overturn rulings through negotiations, sanction agents by not re-appointing them or disregard rulings. Given the rule of state consent, legislative correction of treaties by principals is very difficult. This rigidity of treaties increases the general lawmaking power of courts (Ginsburg 2005:40) and makes evolutionary and gap-filling approaches more likely, a tendency that may increase as time passes and "the 'blanks' between negotiated agreements and current policy issues grow ever bigger" (Levy 2011:50). In terms of reappointment, we expect tribunals where judges are appointed for one term only (especially, a relatively long term) to be less controlled and more activist interpreters (Ehlermann 2002). Ex post control increases where (especially, younger) judges can or must seek reappointment (possible once, for 4 years, in the WTO AB; twice, for 9 
years, at the ICJ). This, in turn, can be expected to limit interpretation space. In terms of disregarding rulings as a form of ex post control, where the cost of exit is high, countries will tolerate adverse rulings. Yet, at some point a line can be crossed where, for example, the benefits of WTO membership no longer outweigh a certain amount or degree of adverse $\mathrm{AB}$ rulings (Helfer 2002). Risk of exit limits interpretation space and should temper activism.

Rhetorical control by principals over tribunals (Helfer and Slaughter 2005; Steinberg 2004) is more subtle and informal, such as discussion and possible criticism of AB rulings by WTO Members in monitoring bodies such as the WTO's Dispute Settlement Body (although AB rulings are automatically adopted, such discussion filters through to the $\mathrm{AB}$ and has, in some cases, influenced and tempered $\mathrm{AB}$ activism, as when the $\mathrm{AB}$ opened proceedings to amicus curiae, a decision which it subsequently, for all practical purposes, reversed after heavy criticism at the DSB).

From the above we generally expect that the greater the interpretation space - all other factors being constant - the more an international tribunal will engage in activist and expansive types of interpretation, in particular witnessed through completing the contract (filling gaps), adopting an evolutionary approach and experimenting with setting precedents.

\section{Interpretation incentives}

The motivations of tribunal members determine how the above-defined interpretation space is used. These intrinsic incentives are causally determined in our framework by two sets of factors: first, institutional factors and second, dominating norms. These supply-side factors (interpretation incentives) interact with the demand-side factors (interpretation space).

\section{Institutional features}

We differentiate three institutional features: a tribunal's lifespan, the composition of constituency and institutional competition.

Tribunal's lifespan: We suggest that whether a tribunal is established as a permanent institution or is created ad hoc (to be distinguished from how individual tribunal members are appointed) strongly determines the motivation of tribunal members. 
Creating a permanent institution suggests that creators substantially support a tribunal and intend to engage in a long-term cooperation with other participating countries. Not surprisingly most standing bodies are created in the context of regional political integration. Normative support of strong principals for a standing tribunal also affects the way judicial agents read their mandate. Similarly, judges develop a more longterm vision. In addition, standing bodies profit from more professional support through established secretariats. Permanent courts are confronted with a stream of cases and are characterized by constant interaction (and learning and adaptation). Taken together, these features allow them to develop more systematic approaches to interpretation (opening up to other fields of international law), including over time more focus on evolutionary interpretation and using precedent to build case law coherence. Ad hoc arbitrators, by contrast, look at interpretation more on a case-bycase basis. Not only is principals' support limited, but also the lack of long term cooperation inhibits the development of systematic approaches to interpretation leading to more attention to parties' intent and originalist and self-contained interpretation.

The composition of constituency: This institutional factor pertains to the question of who has standing, as well as the type of actors that are involved or affected by the work of the tribunal. A tribunal's motivations are shaped by the number of actors involved directly or indirectly in its proceedings. Where a tribunal operates only to solve a dispute between two parties (without affecting other actors), the tribunal will be inclined to focus on party-intent, to reject precedent and to take a more deferential approach to interpretation (as in commercial arbitration and, less so, investor-state arbitration). In contrast, where a tribunal's constituency or audience goes beyond the governments which set up the tribunal (e.g. private traders or investors or individual victims of human rights violations), we expect the tribunal's motivations to differ and to lead more easily to a teleological or more activist interpretation that refers back to earlier case law and draws guidance from a larger interpretative community.

Empirical evidence on the ECJ and the Andean Court of Justice shows that in particular permanent courts attempt to work with lower-level institutions (e.g., national courts) and private actors that pursue similar interests (Alter and Helfer 2011). Where private parties have standing, given the absence of intergovernmental gate-keeping determining which cases will be brought, courts feel inclined to interpret 
rules more in light of individual rights than state-based rights, in turn encouraging other private actors to file or to support the court by following precedents. Private standing will drive courts to test more activist types of interpretation, seeking support for its evolving case law beyond principals. This may explain some of the activism of, for example, the ECHR/IACHR and the ECJ (as well as, less frequently, investorstate arbitrations).

Institutional competition: A specific institutional feature is the presence or absence of alternative courts that parties may turn to. Institutional competition (other courts or other dispute resolution possibilities) allows states to strategically forum-shop to choose the court where they anticipate rulings to be closest to their own preferences (Busch 2007). Therefore, institutional competition may weaken the discretion of judicial agents as they anticipate costs related to forum-shopping. Competition may also come from specialized fields where no tribunals exist (such as international environmental law) but over which a general court (e.g., the ICJ) wants to keep control. Judicial competition, when it comes to interpretation, can also explain why certain tribunals (including the $\mathrm{AB}$ but also the ICJ) have taken a more systemic approach to interpretation. Rather than look inward and construe one's treaty as a selfcontained regime, a tribunal that faces competition, especially from specialized courts, may be inclined to engage with other fields of law and establish connections to previously neglected regimes. This is what we observe at the ICJ, which is engaging more actively with international environmental law, human rights law and even trade and investment law. That in the LaGrand ${ }^{2}$ case, the ICJ finally held that its provisional measures are legally binding has also been explained with reference to a perceived competition with the International Tribunal on the Law of the Sea (ITLOS) whose provisional measures are unquestionably binding. Competition from other courts and tribunals (ICJ, but also NAFTA, investor-state arbitration and ITLOS) may also (partly) explain the AB's increasingly systemic approach to treaty interpretation. In this sense, the proliferation of tribunals may motivate judges to use more systemic interpretation.

\section{Norms} 2 LaGrand (Germany v. United States of America), Provisional Measures, Order of 3 March
1999,I.C.J. Reports 1999, p. 9. 
A second set of factors that impact on supply-side interpretation incentives relate to norms and principles. Tribunal members may have, or may develop, different personal visions of the right role of the court (e.g. more or less deference to the political branch) (Gibson 2006:518), or their precise mandate or the role of international law (in newly created and/or weak countries, international law is more likely to be viewed as supreme). Motivations of judicial agents are also shaped by past experience and individual characteristics which may include ideological and political attitudes (conservative judges, for example, are more likely to defer to national sovereignty and thereby less likely to engage in strong activism) (Segal and Spaeth 1992). In the following we focus on three norm-types of factors that influence the supply side of interpretation: legitimacy, interpretative community and legal tradition.

Legitimacy: Tribunals only function well if their rulings are widely accepted and implemented. As international law lacks the domestic-type enforcement mechanisms, it relies heavily on its decisions being seen as fair and legitimate. This specific compliance pull is pivotal to international tribunals. In this respect, we suggest that young tribunals (such as the early WTO AB) that have not yet established a reputation as a legitimate platform are more reluctant to engage in activist or evolutionary types of interpretation which might easily invite criticism. By contrast, older and established tribunals (such as the more recent $\mathrm{AB}$ ) have more wiggle room. Early case law of the $\mathrm{AB}$ was also characterized by $\mathrm{AB}$ members clearly indicating the interpretative steps (e.g. in relation to sequencing the various steps in the VCLT) as a way to counter potential criticism for lack of coherence (Weiler 2001). Another legitimacy gap may come from the public impression that a tribunal is established by powerful actors and only rules in favour of these actors. In the scenario of courts facing significant criticism from domestic audiences that they have an in-built bias, courts will carefully draft their arguments as a signalling tool to build their overall legitimacy. Therefore if tribunals are young and face "bias" concerns, they may act more timidly than tribunals that are well established and face fewer legitimacy concerns. The designers of the $\mathrm{AB}$ as well as its first seven members were well aware of their difficult task; they saw in the AB "a young plant that needed protection" (Elsig and Pollack 2011). 
Interpretative community: Norms on how to interpret international law may develop differently from one issue area to another. In particular, in some policy domains, there exist shared concepts or closely-knit epistemic or interpretative communities (such as in the field of human rights or early GATT) whereas in other fields disagreements over the meaning of concepts are dominant (e.g. in general international law disputes before the ICJ and, increasingly, trade disputes before the WTO). Shared concepts are often driven by norm entrepreneurs in the creation and diffusion of certain concepts (Keck and Sikkink 1998). Generalist courts (such as the ICJ) may be driven less by value-based interpretations than specialist courts (such as the ECHR or GATT). Over time shared concepts may develop that may substantially differ from one issue area to another. In those cases, interpretation choices can be issue- or field-specific. The more concepts are shared within an issue area the more entrepreneurial the tribunal may act e.g. by adopting a teleological interpretation based on the underlying goals and values shared by the interpretative community in question. We should, in that scenario, witness a preference for gap-filling, evolutionary interpretation and attempts to set precedents. In the context of conflictual concepts (as is often the case, for example, in ICJ disputes) tribunals should be more inclined to operate as work-to-rule agents and abstain from completing the analysis on behalf of principals.

Legal tradition: A particular aspect that may affect treaty interpretation is whether tribunal members (or courts as a whole) are driven by either civil law or common law traditions. This matters in particular when one type dominates over the other. Judicial agents in the civil law tradition are more likely to engage in gap-filling, privileging an evolutionary reading and attempt to build a coherent legal system. Scholars in the tradition of common law, however, will be more likely to abstain from gap-filling and focus on designers' intentions. In term of hermeneutics, they are more likely to rely on textual rather than teleological interpretations (Arnull 2006:612; Lasser 2004). Normative commitments may also derive from a judge's conception of the proper form of argument and persuasion. The ECJ's style of reasoning (and much of that court's success) has, for example, been described as formalist and separate from politics, in line with the generally formalist legal culture of Europe (Shapiro 2002). Other legal traditions that may influence interpretation incentives are, in the context of investor-state arbitration, tribunal members with a commercial law background as 
compared to those with a public international law background (Hirsch 2009). The former are more inclined to focus on party-intention and to settle the dispute between the parties rather than create precedent. Public international lawyers, in contrast, have a tendency to opt for a more textual and systemic interpretation with a role for precedent, reading investment treaties in the light of other rules of international law (Laird 2008:153).

\section{CONCLUSIONS}

This chapter offers a taxonomy of treaty interpretation observed in international courts and tribunals. It lays out five major interpretation choices focused on dominant hermeneutic, timing, activism, precedent and linkage. In addition, the chapter attempts to fill a gap in the literature by formulating a framework to analyse the observed variation across tribunals. We propose two major factors: demand-side interpretation space and supply-side interpretation incentives. We argue that the greater the interpretation space - which, in turn, is determined by contract incompleteness and principals' ability to take collective action - the more likely tribunals are to use expansive strategies. This should be reflected in particular in teleological, evolutionary and gap-filling interpretation techniques. Yet, this interpretation space interacts with a crucial second factor: a tribunal's motivation (interpretation incentives). We have listed institutional factors and norm-type factors which condition a tribunal's motivation. These supply-side incentives may, in turn, steer towards more or less expansive strategies. At this stage, we only provide examples to illustrate our framework. The next step would be to explore in greater detail the interaction effects between interpretation space and interpretation incentives to offer more specific hypotheses to be tested empirically.

We conclude this chapter with a final observation. While debates about treaty interpretation predominantly are about the use of dominant hermeneutics, at this stage, our explanatory variables provide little leverage to capture the fine differences between text, intent and objective. Our - inductively developed - hunch is that the type of hermeneutics is not the best proxy for understanding the intentions or motivations of international tribunals. A tribunal can at times use a textual approach for the same (strict or expansive) purpose it could use an intent-type approach. Therefore systematically suggesting causal arguments when it comes to the dominant 
hermeneutic seems a difficult task as the same type of hermeneutic can be used for different objectives.

\section{References}

Abi-Saab, Georges (2010). "The Appellate Body and Treaty Interpretation," in Malgosia Fitzmaurice, Olufemi Elias and Panos Merkouris (eds.), Treaty Interpretation and the Vienna Convention on the Law of Treaties: 30 Years on (Leiden: Martinus Nijhoff), pp. 99-109.

Abbott, Kenneth, Keohane, Robert, Moravcsik, Andrew, Slaughter, Anne-Marie, and Duncan Snidal (2000). "The Concept of Legalization," International Organization, Vol. 54, No.3, pp. 401-19.

Allott, Philip (1999). "The Concept of International Law," European Journal of International Law, Vol. 10, No. 1, pp. 31-50.

Alter, Karen (2008a). "Agents or Trustees? International Courts in their Political Context," European Journal of International Relations, Vol. 14, No. 1, pp. 33-63.

Alter, Karen (2008b). "Delegating to International Courts: Self-Binding vs. OtherBinding Delegation," Law and Contemporary Problems, Vol. 71, No. 1, pp. 37-76.

Alter, Karen, and Laurence Helfer (2011). "Nature or Nurture? Judicial Lawmaking in the European Court of Justice and the Andean Tribunal of Justice," International Organization, Vol. 64, No. 4, pp. 563-92.

Arnull, Anthony (2006). The European Union and its Court of Justice, 2nd edn (Oxford: Oxford University Press).

Bankowski, Zenon, MacCormick, Neil, Summers, Robert, and Jerzy Wroblewski (1991). "On Method and Methodology," in Neil MacCormick and Robert Summers (eds.), Interpreting Statutes: A Comparative Study (Brookfield, VT: Dartmouth), pp. 9-27. 
Bianchi, Andrea (2010). “Textual Interpretation and (International) Law Reading: the Myth of (In)determinacy and the Genealogy of Meaning," in Pieter Bekker, Rudolf Dolzer and Michael Waibel (eds.), Making Transnational Law Work in the Global Economy: Essays in Honour of Detlev Vagts (Cambridge: Cambridge University Press), pp. 34-55.

Busch, Marc (2007) "Overlapping Institutions, Forum Shopping, and Dispute Settlement in International Trade," International Organization, Vol. 61, No. 4, pp. 735-61.

Caron, David (2007). "Towards a Political Theory of International Courts and Tribunals,” Berkeley Journal of International Law, Vol. 24, pp. 401-22.

Crema, Luigi (2010). "Disappearance and New Sightings of Restrictive Interpretation(s)," European Journal of International Law, Vol. 21, No. 3, pp. 681700.

David, Felix (2009). "The Role of Precedent in the WTO - New Horizons?" Maastricht Faculty of Law Working Paper No.12.

Davis, Christina (2011). "WTO Adjudication as a Tool for Conflict Management", Paper presented at the 4th Political Economy of International Organizations Conference, Zurich.

DiMascio, Nicholas, and Joost Pauwelyn (2008) "Non-Discrimination in Trade and Investment Treaties: Worlds Apart or Two Sides of the Same Coin?" American Journal of International Law, Vol. 102, No. 1, pp. 48-89.

Drezner, Daniel (2006). "The Viscosity of Global Governance: When is ForumShopping Expensive?" Paper presented at the American Political Science Association Annual Meeting, Philadelphia. 
Ehlermann, Claus-Dieter (2002). "Six Years on the Bench of the 'World Trade Court', Some Personal Experiences as Member of the Appellate Body of the WTO," Journal of World Trade, Vol. 36, No. 4, pp. 605-39.

Elsig, Manfred, and Mark Pollack (2011). “Agents, Trustees, and International Courts: Nomination and Appointment of Judicial Candidates in the WTO Appellate Body." Paper presented at the Annual Meeting of the International Studies Association, Montreal.

Fachiri, Alexander (1929). "Interpretation of Treaties," American Journal of International Law, Vol. 23, pp. 745-52.

Fauchald, Ole Kristian (2008). "The Legal Reasoning of ICSID Tribunals: An Empirical Analysis," European Journal of International Law, Vol. 19, No. 2, pp. 30164.

Ferejohn, John (2002). "Judicializing Politics, Politicizing Law", Law and Contemporary Problems, Vol. 65, No. 3, pp. 41-68.

Gardiner, Richard (2008). Treaty Interpretation (Oxford: Oxford University Press).

Gibson, James (2006). “Judicial Institutions," in R.A.W. Rhodes, Sarah Binder and Bert Rockman (eds.), The Oxford Handbook of Political Institutions (Oxford: Oxford University Press), pp. 514-34.

Ginsburg, Tom (2005). "International Judicial Lawmaking," available at: http://works.bepress.com/tom_ginsburg/10

Gordon, Edward (1965). "The World Court and the Interpretation of Constitutive Treaties," American Journal of International Law, Vol. 59, No. 4, pp. 794-833.

Grant, Ruth, and Robert Keohane (2005). “Accountability and Abuses of Power in World Politics," American Political Science Review, Vol. 99, No. 1, pp. 29-43. 
Grover, Leena (2010). "A Call to Arms: Fundamental Dilemmas Confronting the Interpretation of Crimes in the Rome Statute of the International Criminal Court," European Journal of International Law, Vol. 21, No. 3, pp. 543-83.

Helfer, Laurence, and Anne-Marie Slaughter (2005). "Why States Create International Tribunals: A Response to Professors Posner and Yoo," California Law Review, Vol. 93, No. 3, pp. 899-956.

Helfer, Laurence (2002). "Overlegalizing Human Rights," Columbia Law Review, Vol. 102, No. 7, pp. 1832-911.

Hirsch, Moshe (2009). "Investment Tribunals and Human Rights : Divergent Paths," in Pierre-Marie Dupuy, Francesco Francioni and Ernst-Ulrich Petersmann (eds.), Human Rights in International Investment Law and Arbitration (Oxford: Oxford University Press), pp. 97-114.

Howse, Robert (2000). "Adjudicative Legitimacy and Treaty Interpretation in International Trade Law: The Early Years of the WTO," in Joseph Weiler (ed.), The EU, the WTO and the NAFTA: Towards a Common Law of International Trade? (Oxford: Oxford University Press), pp. 35-70.

Jacob, Marc (2011). "Precedents: Lawmaking Through International Adjudication," German Law Journal, Vol. 12, No. 5, pp. 1005-32.

Kearney, Richard, and Robert Dalton (2004). "The Treaty on Treaties," in Scott Davidson (ed.), The Law of Treaties (Burlington, VT: Ashgate), pp. 3-72.

Keck, Margaret, and Kathryn Sikkink (1998). Activists Beyond Borders (Ithaca: Cornell University Press).

Klabbers, Jan (2010). "Virtuous Interpretation," in Malgosia Fitzmaurice, Olufemi Elias and Panos Merkouris (eds.), Treaty Interpretation and the Vienna Convention on the Law of Treaties: 30 Years on (Leiden: Martinus Nijhoff), pp. 17-37. 
Koremenos, Barbara (2007). "If Only Half of International Agreements Have Dispute Resolution Provisions, Which Half Needs Explaining?” Journal of Legal Studies, Vol. 36, No. 1 pp. 189-212.

Kuijper, Pieter Jan (1994). "The Law of GATT as a Special Field of International Law," Netherlands Yearbook of International Law, Vol. 25, pp. 227-57.

Kuijper, Pieter Jan, and Marco Bronckers (2005). "WTO Law in the European Court of Justice," Common Market Law Review, Vol. 42, No. 5, pp. 1313-55.

Laird, Ian (2008). "Interpretation in International Arbitration - Through the Looking Glass," in Jacques Werner and Arif Hyder Ali (eds.), A Liber Amicorum: Thomas Wälde - Law Beyond Conventional Thought (London: Cameron May), pp. 151-164.

Lasser, Mitchel (2004). Judicial Deliberations: A Comparative Analysis of Judicial Transparency and Legitimacy (Oxford: Oxford University Press).

Lauterpacht, Hersch (1949). "Restrictive Interpretation and the Principle of Effectiveness in the Interpretation of Treaties," British Yearbook of International Law, Vol. 26, No. 48, pp. 49-85.

Lauterpacht, Hersch (1950). "De l'Interprétation des Traités: Rapport," Annuaire de l'Institut du Droit International, Vol. 43, No. 2, pp. 366-400.

Lenaerts, Koen (2007). "Interpretation and the Court of Justice: a Basis for Comparative Reflection," The International Lawyer, Vol. 41, No. 4, pp. 1011-32.

Letsas, George (2010). "Strasbourg's Interpretive Ethic: Lessons for the International Lawyer,” European Journal of International Law, Vol. 21, No. 3, pp. 509-41.

Levy, Philip (2011). "Doha Round: Keep Moving Forward or Fall Down," in Richard Baldwin and Simon Evenett (eds.), Why World Leaders Must Resist the False Promise of Another Doha Delay, Why World Leaders Must Resist the False Promise 
of Another Doha Delay, (eBook, available at www.voxeu.org/reports/Doha.pdf), pp. 47-54.

Lixinski, Lucas (2010). "Treaty Interpretation by the Inter-American Court of Human Rights: Expansionism at the Service of the Unity of International Law," European Journal of International Law, Vol. 21, No. 3, pp. 585-604.

Mattli, Walter, and Anne-Marie Slaughter (1998). "Revisiting the European Court of Justice,” International Organization, Vol. 52, No. 1, pp. 177-209.

McGinnis, John, and Mark Movsesian (2000). "The World Trade Constitution," Harvard Law Review, Vol. 114, No. 2, pp. 511-605.

McDougal, Myres (1967). “The International Law Commission’s Draft Articles Upon Interpretation: Textuality Redivivus," American Journal of International Law, Vol. 61, No. 4, pp. 992-1000.

McDougal, Myres, Lasswell, Harold and James Miller (1967). The Interpretation of International Agreements and World Public Order: Principles of Content and Procedure (Dordrecht: Martinus Nijhoff).

Milanovic, Marko (2009). "The ICJ and Evolutionary Interpretation," European Journal of International Law: Talk!, available at http://www.ejiltalk.org/the-icj-andevolutionary-treaty-interpretation/

Nielson, Daniel, and Michael Tierney (2003). "Delegation to International Organizations: Agency Theory and World Bank Environmental Reform," International Organization, Vol. 57, No 2, pp. 241-76.

Okowa, Phoebe (2010). "Interpreting Constitutive Instruments of International Criminal Tribunals: Reflections on the Special Court for Sierra Leone," in Malgosia Fitzmaurice, Olufemi Elias and Panos Merkouris (eds.), Treaty Interpretation and the Vienna Convention on the Law of Treaties: 30 Years on, (Leiden: Martinus Nijhoff), pp. 333-55. 
Orakhelashvili, Alexander (2008). The Interpretation of Acts and Rules in Public International Law (Oxford: Oxford University Press).

Pauwelyn, Joost (2003). Conflict of Norms in Public International Law (Cambridge: Cambridge University Press).

Payne, Cymie (2010). "Pulp Mills on the River Uruguay: The International Court of Justice Recognizes Environmental Impact Assessment as a Duty under International Law," American Society of International Law Insight, Vol. 14, No. 9.

Posner, Eric, and John Yoo (2005). "Judicial Independence in International Tribunals," California Law Review, Vol. 93, No. 1, pp. 1-94.

Rasmussen, Hjalte (1986). On Law and Policy in the ECJ. A Comparative Study in Judicial Policymaking (Dordrecht: Martinus Nijhof).

Roberts, Anthea (2008). "Power and Persuasion in Investment Treaty Interpretation: The Dual Role of States," American Journal of International Law, Vol. 104, No. 2, pp. 179-225.

Romani, Carlos (2007). Sovereignty and Interpretation of International Norms (Heidelberg: Springer).

Romano, Cesare (2007). "The Shift from the Consensual to the Compulsory Paradigm in International Adjudication: Elements for a Theory of Consent," NYU Journal of International Law and Politics, Vol. 39, No. 4, pp. 791-872.

Rosenne, Shabtai (2006). The Law and Practice of the International Court, 19202005, vol. III, 4th edn (Leiden: Martinus Nijhoff).

Schabas, William (2003). "Interpreting the Statutes of the Ad Hoc Tribunals'," in Lal Chand Vohrah et al. (eds.), Man's Inhumanity to Man, Essays on International law in Honour of Antonio Cassese (The Hague: Kluwer), pp. 847-88. 
Schill, Stephan (2010). “Glamis Gold, Ltd. V. United States," American Journal of International Law, Vol. 104, No. 2, pp. 253-58.

Schreuer, Christoph (2010). "Diversity and Harmonization of Treaty Interpretation in Investment Arbitration," in Malgosia Fitzmaurice, Olufemi Elias and Panos Merkouris (eds.), Treaty Interpretation and the Vienna Convention on the Law of Treaties: 30 Years on (Leiden: Martinus Nijhoff), pp. 129-51.

Segal, Jeffrey, and Harold Spaeth (1992). The Supreme Court and the Attitudinal Model (New York: Cambridge University Press).

Shapiro, Martin (2002). "The Success of Judicial Review and Democracy," in Martin Shapiro and Alec Stone Sweet (eds.), On Law, Politics, and Judicialization (Oxford: Oxford University Press), pp. 149-83.

Steinberg, Richard (2004). "Judicial Lawmaking at the WTO: Discursive, Constitutional, and Political Constraints," American Journal of International Law, Vol. 98, No. 2, pp. 247-75.

Swart, Mia (2010). "Is There a Text in This Court? The Purposive Method of Interpretation and the Ad Hoc Tribunals," Zeitschrift für Ausländisches Öffentliches Recht und Völkerrecht, Vol. 4, No. 3, pp. 767-88.

Torres Bernardez, Santiago (1998). "Interpretation of Treaties by the ICJ following the Adoption of the 1969 Vienna Convention on the Law of Treaties," in Gerhard Hafner et al. (eds.), Liber Amicorum, Professor Seidl-Hohenveldern (The Hague: Kluwer), pp. 721-48.

Van Damme, Isabelle (2009). Treaty Interpretation by the WTO Appellate Body (Oxford: Oxford University Press). 
Voeten, Erik (2007). “The Politics of International Judicial Appointments: Evidence from the European Court of Human Rights," International Organization, Vol. 61, No. 4, pp. 669-701.

Voeten, Erik (2008). “The Politics of International Judicial Appointments,” American Political Science Review, Vol. 102, No. 4, pp. 417-33.

Weiler, Joseph (2001). "The Rule of Lawyers and the Ethos of Diplomats", Journal of World Trade, Vol. 35, No. 2, pp. 191-207.

Weiler, Joseph (2008). "Prolegomena to a Meso-theory of Treaty Interpretation at the Turn of the Century," draft available at www.iilj.org/courses/documents/2008Colloquium.Session5.Weiler.pdf.

Weiler, Joseph (2010). "The Interpretation of Treaties - A Re-examination Preface," European Journal of International Law, Vol. 21, No. 3, p. 507. 